\title{
Literation Instruments Learning Physical Student Education Through Student Worksheet (SW)
}

\author{
${ }^{1}$ Akbar Zahriali, ${ }^{2}$ Tarsyad Nugraha, ${ }^{3}$ Hariadi \\ ${ }^{1}$ Program Pascasarjana Universitas Negeri Medan \\ Medan, Indonesia \\ 1akbarzahriali1993@gmail.com
}

\begin{abstract}
This study aims to determine literacy skills in reading students by using Student Worksheets (SW); to find out the learning outcomes of students through SW on physical education subjects in school education; to find out the difference in literacy skills of reading students at junior high school level. This study uses mixed methods (mixed methods) with convergent design. The population in the study was all junior high school level in Bandung. The subjects in this study were students of Junior High School 1 in Bandung and Junior High School 1 in Bandung. While the object or phenomenon is analyzed by the level of literacy of students in physical education subjects. The instrument used to analyze the relationship of physical education learning of students with literacy reading through the SW. SW is one of the means to help and facilitate teaching and learning activities so that effective interactions between students and educators will be formed, so as to improve the activities of students in improving learning achievement. The description of the data presented in this study comes from the data collected during the study, namely literacy reading abilities of students using SW in physical education subjects. The making of the SW practice instrument for this study refers to the making of the Progress in International Reading Literacy Study (PIRLS) literacy survey. The research data were in the form of the average scores of $\mathrm{SW}$ from Practice Questions 1, 2 and 3 in Junior High School 1 in Bandung to 86 and Junior High School 6 in Bandung at 88. On the results of the average score of workmanship of the superior SW was Junior High School 6 in Bandung.
\end{abstract}

Keywords: Instrument, Learning Literacy, Physical Education, Student Worksheet (SW)

\section{INTRODUCTION}

The meaning of education in a simple way can be interpreted as a human effort to hone his personality ability to have intelligence, religious spiritual strength needed by himself and the community environment. Education is one of the means in the formation of quality human resources so that it is beneficial for the survival and progress of the nation's life. Indonesia is a country that prioritizes education for its people nationally. The quality of education in Indonesian society can be obtained through formal education in a general nature.

The curriculum is the heart of the world of education. (Curriculum Center Research and Development Agency,
2007) [4]. Curriculum changes can be seen as the right way to improve the quality of education in Indonesia. The main key to achieving success in striving to improve the quality of education programs is the implementation of a quality learning process (Widoyoko, 2008) [7]. This opinion is in accordance with Djohar's (2003) statement that curriculum improvement must be accompanied by improvements in learning practices [2]. Changes to the curriculum without accompanied by changes in praxis of learning will not produce anything. The description can be stressed that the implementation of the physical education curriculum must be carried out by carrying out an optimal learning process, in this case must be in accordance with the demands of the process standards set by the BSNP. In this regard, efforts to improve the quality of education must begin by improving the quality of the learning process. Learning is a process of interaction between students, educators, and learning resources in a learning environment (Article 1 paragraph 20 of the National Education System Law Number 20 of 2003) [6]. Based on this description, it is clear that the process of learning quality physical education is the key to the successful implementation of the physical education curriculum to achieve good quality education.

The government continues to improve education problems nationally, one of which can be seen from the low learning literacy of students. Literacy about the ability of individuals to read, write, speak, count, and solve problems at the level of expertise needed in work, family and society. The low literacy of students is emphasized through data on the Program for International Students Assessment (PISA) \& Progress in International Reading Literacy Study (PIRLS) literacy institutions from 2000 to 2015 held in these three years, presented in Table I.

TABLE I. RESULTS OF PISA \& PIRLS LITERACY SURVEY

\begin{tabular}{ccccc}
\hline No & Years & $\begin{array}{c}\text { Survey } \\
\text { Institute }\end{array}$ & $\begin{array}{c}\text { Rank/Position } \\
\text { Literacy } \\
\text { Participants }\end{array}$ & $\begin{array}{c}\text { Number of } \\
\text { Participants }\end{array}$ \\
\hline 1 & 2000 & PISA & 39 & 41 \\
2 & 2003 & PISA & 39 & 40 \\
3 & 2006 & PIRLS & 41 & 45 \\
\hline
\end{tabular}




\begin{tabular}{ccccc}
\hline 4 & 2009 & PISA & 59 & 65 \\
5 & 2012 & PIRLS & 64 & 65 \\
6 & 2015 & PIRLS & 64 & 72 \\
\hline \multicolumn{5}{c}{$\begin{array}{c}\text { Indonesian literacy average of 383 students } \\
\text { still far below the average of 501 }\end{array}$} \\
\hline \multicolumn{5}{c}{}
\end{tabular}

The latest PISA and PIRLS literacy survey results in 2015 Indonesia was in 64th position of the total 72 participants in the world. This data shoSW that education literacy is still low in Indonesia. This was also found by researchers when conducting observations to schools, especially in the Medan, North Sumatra areas where the literacy results of students and sources of literacy were still low such as the Student Worksheet (SW) books, libraries, electronic books, computers with internet networks.

Based on preliminary observations and intervieSW with classroom teachers in several schools in junior high schools around Medan Johor, in fact teachers did not know the reading literacy skills of students especially in physical and sports education subjects using SW. The teacher should be able to balance the cognitive intellectual intelligence of students with psychomotor abilities in the environment. The teacher is expected to use a companion book learning tool that is able to support learning optimally, for example by using SW.

The Republic of Indonesia law on national education system number 20 of 2003 concerning the implementation of national education states that education is carried out by developing a culture of reading, writing and arithmetic for all citizens. This is also stated in the Education for All (EFA) program or EFA under the coordination of the United Nations for 164 countries in the world who participate in literacy program membership. The literate community is characterized by the willingness and ability of the community to read (Suryaman, 2001) [5].

Many factors determine the quality of national education in the eyes of the International. Improving the quality of national education must begin with improving the quality of the components of education itself. One of them is to increase learning in physical education subjects contained in the current national education curriculum. SW in physical education subjects is an alternative to improve the literacy of students' learning outcomes. SW as a form of learning process that must follow the principles of effective teaching and learning. SW can be read, studied and understood by students themselves individually or taught by students themselves (selfinstructional). The quality of education starts from school. Every country has a formal education system in schools which is generally mandatory. So the school must have an alternative means of learning tools in addition to books. SW is one of the means to find out the literacy and cognitive abilities of students. A good SW is an attractive SW and can invite students to have good cognitive, affective and psychomotor skills in accordance with the applicable curriculum.

The Indonesian Republic of Indonesia Law number II of 1989 concerning the National Education System that the purpose of education including physical education in Indonesia is the development of Indonesian people as a whole is human beings who have faith and are devoted to God Almighty and virtuous, possess knowledge and skills, physical and spiritual health, a strong and independent personality and a sense of civic responsibility and nationality. Physical education is part of education in general. It is one of the subsystems - the education subsystem.

Physical education can be defined as an educational process aimed at achieving educational goals through physical movement. It has become a common fact that physical education as a general fact that physical education as a substance of education has a meaningful role in developing the quality of Indonesian human beings. Indonesian human qualities must have intellectual intelligence from reading literacy and prime health from physical education in formal school institutions.

Reading literacy skills must be accompanied by excellent physical health from an early age. The 2013 Basic Health Research (BHR) data shoSW that Indonesian people's fitness level is still low. Noted, only $17 \%$ of the population has a good physical fitness degree. The community is also encouraged to run regular exercise to improve fitness. "Based on data from Kemenpora, only 1 in 4 Indonesians are diligent in exercising. The level of sports participation of residents aged 10 years and over in 2003 - 2012 shoSW a downward trend, from $25 \%$ to 24\%," said Deputy for Sports Culture Ministry of Youth and Sports (Kemenpora) A low level of fitness will adversely affect the health of people in their 40s who have been exposed to degenerative diseases, such as heart attacks and strokes. "Health must be invested as early as possible so that the disease decreases." To initiate exercise habits, the community must choose the type of exercise that suits their interests and abilities for that the formal education system in schools must be able to be a means for every student, as early as possible to have intelligence and physical fitness.

\section{METHODS}

The study population was all junior high schools in Medan Johor and the sample of this study were teachers and students in Bandung High School in the 2018/2019. This research is a mixed methods research with convergent design. According to Creswell, J (2015) "Mixed methods design is a procedure for collecting, analyzing, and mixing kuanlitatif and qualitative methods in a study or series of studies to understand research problems" Creswell, J (2015) suggests that " kgengen design is a research procedure that collects quantitative and qualitative data simultaneously, combines the data, compares the results, and explains all descriptions in the results " [1]. Likewise with 
the procedures applied in this study. This study uses questionnaire and observation sheets to obtain quantitative data, and interview guidelines to obtain qualitative data, then the quantitative and qualitative data are analyzed together by combining, comparing, and explaining each instrument description or indicator so that it can answer questions. more perfect research [8].

Data was collected using a mixed-method approach, beginning with the use of quantitative methods followed by qualitative methods. Quantitative data on the use of SW by students was collected using a questionnaire. The questionnaire was developed by modifying the steps of Madaus et al., Claeys et al., And Wheeler, through the literature review stage, constructing instruments, determining content validity by expert validation, and field trials [8]. Qualitative data about the physical education learning process and other qualitative data, obtained through observation, making field notes, categorizing field notes, and in-depth intervieSW. All data were analyzed with explanatory mixedmethod analysis.

According to Wikipedia (2018) research subjects or respondents are the parties used as samples in a study. Research subjects also discussed the characteristics of the subjects used in the study, including explanations of population, samples and sampling techniques (random or nonrandom) used. [9] The subject of this research produced information that was drawn and developed purposively. Subjects in this study were teachers and students involved in the process of learning physical education which was held at the Medan Johor junior high school chosen based on certain considerations. While the object or phenomenon of this research is the level of reading literacy, the activities of students and teachers, and the physical education learning process that is chosen to be observed with certain considerations.

This research is developing SW instruments. This is in accordance with the opinion of Fletcher - Campbell et al in PIRLS (2011) that literacy is a complex concept so that to get this ability is needed a complicated process [3]. The complexity of literacy is simplified by PIRLS, PISA, and TIMSS by limiting the classification of literacy levels based on strand, level of cognition, type and type of text (in reading literacy), and literary context. The construct produced is in accordance with the "warning" that literacy is not just the ability to read and write but the relationship between that ability and the environment, both at the local, regional and transnational levels. The instrument was developed by modifying the steps taken by PISA and PIRLS literacy through the literature review stage, constructing instruments according to Low cognitive level (Knowing \& Understanding Facts); Intermediate (Analyze \& Organize); High (Summing \& Interpreting) and Advanced (Synthesis, Imagination, Creation), then instrument validity through expert agreement, and field trials.

\section{RESULTS AND DISCUSSION}

The results of this study consist of two categories, namely quantitative results and qualitative results. The results of quantitative research in this study inform the level of reading literacy using SW in junior high schools in Johor. This data illustrates the level of reading literacy used by students during physical education. Quantitative data shoSW that the level of reading literacy using $\mathrm{SW}$ in the learning of physical education in the odd semester of junior high school has not reached the good category.

Based on qualitative data it can be obtained information that physical education learning activities in Johor Johor Junior High School are still dominated by direct practice oriented learning practices. In the intended learning activities, the teacher acts more as the main speaker and rarely reads the text of the book. Physical education learning activities are still dominated by communication activities (communicating), both in the form of oral communication, while observing the object of study in the form of original objects is still very limited.

The results of other qualitative studies are the results of intervieSW with physical education subject teachers, which inform their perception of the implementation of reading literacy in physical education learning. The interview results provide information that the teacher cannot carry out physical education learning activities that are fully in accordance with the plan (which is written in the RPP). In this case the teacher estimates the level of implementation of the plans they make varies, some estimate around $25-50 \%$ because the Ministry of Education and Culture (Kemendikbud) changes the teacher's obligation to teach for 24 hours as a condition to get professional allowances to 40 hours work in a week. The obligation of 40 hours of work per week is divided into five tasks called 5M, namely planning learning, carrying out faceto-face teaching, assessing or scoring the learning outcomes of students, carrying out guidance, and carrying out additional tasks such as scouting or being a homeroom teacher. The burden of the task is the difficulty of the teacher to deliver the material and work on the SW in the classroom.

\section{CONCLUSIONS}

The conclusions of this study is that the quality of reading literacy using SW instruments in physical learning held in Junior High School in Bandung has not reached the good category. This is marked by the presence of teachers who focus on teaching direct practice of physical education to students compared to literacy skills reading physical learning material. The main supporting factors in the implementation of literacy in physical education in Junior High School 1 in Bandung are the facilities available at school and the high commitment of teachers to implement literacy. 


\section{REFERENCES}

[1] Creswell, J. 2015. Riset Pendidikan, Yogyakarta : Pustaka Pelajar.

[2] Djohar. 2003. Gambaran umum program pembaharuan pendidikan MIPA dan bahasa inggris. Prosiding. Seminar Penataran Guru Penelitian di YAMB, Yogyakarta.

[3] PIRLS 2011 International Report. 2011. Performance at the PIRLS 2011. International Benchmarks TIMMS \& PIRLS Report International Study Center (IEA): Lynch School of Education, Boston College.

[4] Pusat Kurikulum Badan Penelitian dan Pengembangan. 2007. Naskah akademik kebijakan kurikulum mata pelajaran IPA. Jakarta: Depdiknas RI.

[5] Suryaman, Maman. 2001. "Kesiapan Masyarakat Sunda Menghadapi Era Global", Prosiding. Makalah pada Konferensi Internasional Budaya Sunda (The Indonesian Conference on Sundanesse Culture), Gedung Merdeka, Bandung, 22-25 Agustus 2001.

[6] Undang - undang Sisdiknas nomor 20 tahun 2003

[7] Widoyoko, S. P. (2008). Peranan evaluasi program pembelajaran dalam mening-katkan kualitas pendidikan. Makalah penyerta disampaikan dalam Seminar Strategi Peningkatan Kualitas Pendi-dikan pada tanggal 22 Maret 2008, di PPS UNY, Yogyakarta. Kerjasama PPS UNY- HEPI

[8] Wiwi, I dan Kumaidi. 2015. Evaluasi Implementasi PKP Dalam Pembelajaran Biologi Di SMAN Kota Semarang Menggunakan Pendekatan Mixed-Method. Jurnal Penelitian dan Evaluasi Pendidikan. Volume 19, No 1, Juni 2015 (109-121).

[9] Wikipedia [Online]. Tersedia di https://id.wikipedia.org/wiki/Subjek_penelitian. Diakses 27 agustus 2018. 